$\begin{array}{ll} & \text { Etnográfica } \\ \text { etnográfica } & \text { Revista do Centro em Rede de Investigação em }\end{array}$

Antropologia

vol. 20 (3) | 2016

Vol. 20 (3)

\title{
Bakhtinianas: usar Mikhail Bakhtin para a etnografia das práticas quotidianas do trabalho
}

Bakhtiniana: using Mikhail Bakhtin to the ethnography of the everyday

practices of work

\section{Bruno Monteiro}

\section{(2) OpenEdition}

Journals

Edição electrónica

URL: https://journals.openedition.org/etnografica/4617

DOI: 10.4000/etnografica.4617

ISSN: 2182-2891

\section{Editora}

Centro em Rede de Investigação em Antropologia

\section{Edição impressa}

Data de publição: 1 outubro 2016

Paginação: 443-469

ISSN: 0873-6561

\section{Refêrencia eletrónica}

Bruno Monteiro, «Bakhtinianas: usar Mikhail Bakhtin para a etnografia das práticas quotidianas do trabalho », Etnográfica [Online], vol. 20 (3) | 2016, posto online no dia 27 novembro 2016, consultado o 09 fevereiro 2022. URL: http://journals.openedition.org/etnografica/4617 ; DOI: https://doi.org/ 10.4000/etnografica.4617

\section{(c) (i) (8)}

Etnográfica is licensed under a Creative Commons Attribution-NonCommercial 4.0 International License. 


\section{Bakhtinianas: usar Mikhail Bakhtin para a etnografia das práticas quotidianas do trabalho}

\section{Bruno Monteiro}

Neste texto vamos mostrar, a partir de uma pesquisa sobre o mundo do trabalho industrial, a relevância que têm as propostas intelectuais de Mikhail Bakhtin para a etnografia. Depois de procedermos a uma caracterização do terreno de pesquisa, salientamos a pertinência que têm noções como "eventicidade", "contexto de enunciação" e "cronotopo" para a etnografia. Estas noções não são tratadas com pretensões hermenêuticas, mas sempre para mostrar a sua heuristicidade para a pesquisa etnográfica das práticas quotidianas do trabalho. $\mathrm{O}$ texto termina avançando uma proposta de sintonização da etnografia com as exigências do modo de "pensamento participativo". A implicação imediata do investigador com os eventos concretos e singulares, sem renunciar, muito pelo contrário, ao uso de instrumentos conceptuais da autorreflexividade, torna salientes os limites e virtualidades do entendimento da etnografia como processo de conhecimento em ato.

PALAVRAS-CHAVE: Bakhtin, etnografia do trabalho, eventicidade, cronotopo, pensamento participativo.

Bakhtiniana: using Mikhail Bakhtin to the ethnography of the everyday practices of work - In this paper, we try to show, starting from a research on the industrial work, the relevance that Mikhail Bakhtin's intellectual proposals have for the ethnography. After the characterization of the site of inquiry, we highlight the epistemic value of notions such as "eventness", "context of enunciation" and "chronotope". These notions are not treated under hermeneutic intentions, but always to point out their heuristic potential for the ethnography of everyday practices of working. The paper ends with the suggestion of tuning up the ethnography with the requirements of "participative thinking." The immediate engagement of the researcher on unique and concrete events, while still allowing for the use of conceptual instruments and procedures of self-reflection, also shows the limits and virtues of understanding the ethnography as a process of knowledge in act.

KEYWORDS: Bakhtin, ethnography, eventness, chronotope, participative thinking.

MONTEIRO, Bruno (bjrmonteiro@gmail.com) - Instituto de Sociologia, Universidade do Porto; Instituto de História Contemporânea, Universidade Nova de Lisboa, Portugal. 
O RELACIONAMENTO COM AUTORES, TEXTOS OU CONCEITOS ENTREtanto integrados no "cânone" académico não está restringido à exegese. ${ }^{1}$ Uma via alternativa consiste em tirar os autores, conceitos e textos do seu casulo original para, literalmente, os "pôr a trabalhar". Fazer "trabalhar um conceito" corresponde, para Georges Canguilhem (1990: 206), a uma postura epistemológica que vê na investigação científica uma prática aplicada e não uma atitude de contemplação. No nosso trabalho de pesquisa etnográfica sobre a experiência quotidiana de uma comunidade industrializada (Rebordosa, no concelho de Paredes), realizado em 2007 e 2008, pudemos testar sobre o terreno um programa de investigação que surgiu da imersão prolixa e prolongada nos textos de Mikhail Bakhtin. ${ }^{2}$ Esta imersão foi-nos paulatinamente impregnando com o seu enxame de interrogações, orientações e preocupações a respeito da centralidade da vida prosaica. Até então flutuando liquefeitas em solução, uma terminologia e uma tecnologia de pesquisa puderam tornar-se, em virtude da sua condensação sobre um terreno de inquérito em concreto, conceitos operatórios: já não apenas tópicos convencionais ou termos soltos, mas também instruções de observação, registo e interpretação do mundo social. A invocação de Mikhail Bakhtin nas ciências sociais acumulou entretanto uma densa história (Brandist e Tihanov 2000; Hirschkop e Sheperd 2001); este texto não pretende, a este título, nenhuma originalidade. Aqui, para verificar a proficuidade da perspetiva intelectual de Mikhail Bakhtin para a etnografia, estamos interessados em concretizar, aplicar, em sentido estrito, o sistema de conceitos que subjaz aos seus textos a um caso particular do mundo social, mais do que impor uma visão ortodoxa a respeito do seu contributo teórico.

O círculo da controvérsia onde alternativas exegéticas concorrem pela imposição de uma versão canónica a respeito de um conceito, autor ou método arrasta usualmente consigo a inconsciência dos contraventores sobre os pressupostos em que assenta essa altercação (vd. Gingras 2014); em contrapeso,

I Bruno Monteiro é bolseiro de pós-doutoramento com o apoio da Fundação para a Ciência e a Tecnologia (SFRH/BPD/85086/2012).

2 A natureza de "inacabamento" que tem a relação que mantemos com a obra de Mikhail Bakhtin plasma-se nitidamente neste texto, em que, mais do que uma "recensão", procurámos concretizar uma implicação crítica com a sua obra por via da sua aplicação à pesquisa etnográfica. Neste artigo, retomámos, ampliámos e corrigimos explorações que conduzimos anteriormente sobre este mesmo tema (Monteiro 2014a, 2014b). Esta nossa contribuição, que, insistimos, permanece uma criação em aberto, aproveitou o intercâmbio intelectual mantido com outros colegas, interessados por temas próximos destes. Sem caráter de exaustividade, vale a pena salientar a generosidade de Carlos Alberto Faraco, Cristovão Tezza, Nuno Venturinha, Simon Charlesworth, Nuno Domingos, Ari Sitas, Sumangala Damodaran, Nikos Trimikliniotis, Amrita Pande e Wiebke Keim. Queríamos ainda agradecer aos dois avaliadores anónimos que a Etnográfica destacou para este texto: aproveitámos, tanto quanto pudemos, os seus comentários e sugestões. Retomando as palavras de Mikhail Bakhtin, assumimos por completo a "responsabilidade" pelas limitações do presente texto, sem procurarmos um "álibi” nos conselhos e críticas que recebemos. 
remeteremos oportunamente para o contexto histórico de incubação das propostas de desenvolvimento e superação da herança neokantiana que foram avançadas ao longo dos primeiros 20 anos do século XX, entre as quais se incluem os trabalhos iniciais de Mikhail Bakhtin (Godzich 1991). Dissemos já que o presente texto procura trazer uma aplicação mais do que uma interpretação ortodoxa do trabalho de Mikhail Bakhtin, menos ainda a sua catalogação entre as controvérsias a respeito da receção da sua obra. Eventualmente por isso, a visão apresentada neste texto comporta um imperfeito alinhamento com as partes em disputa na importante polémica sobre a integração do trabalho de Mikhail Bakhtin por correntes de pensamento associadas ao "pós-modernismo" (sobre estes posicionamentos, vd. Adlam 2001: 247-248) ou, em sentido inverso, a sua sinalização como mecanismo de compensação contra as versões mais extremas do relativismo ou "dissolução do sujeito" (Gardiner 2003). Michael Gardiner, aliás, salienta que a obra de Mikhail Bakhtin surge extemporaneamente investida quando transposta para os termos desta polémica, pois o seu contexto de enunciação inicial (histórico, tal como intelectual) era completamente outro: inserido neste, Mikhail Bakhtin "evita os extremos gémeos do absolutismo moral e do 'tudo serve' do relativismo pós-moderno" (2003: xii). A este respeito, talvez seja importante registar, como sugere Peter Hitchcock, a distinção existente entre o "Mikhail Bakhtin" que os partidos antagonistas constroem à sua imagem e semelhança e o Mikhail Bakhtin em ação sobre o contexto histórico em que estava (vd. Gardiner 2003: xiii).

Tendo em vista a economia da exposição, iremos sobretudo concentrar-nos sobre o nosso trabalho de observação participante, em que trabalhámos como manobrador de máquinas - leia-se: aprendiz ou auxiliar de "maquinista" numa empresa de mobiliário por um período de 14 semanas. Vamos, assim, recorrer extensivamente às nossas notas de campo, procurando trazer para a superfície aparentemente inócua do papel as tribulações que o trabalho etnográfico comportou. Os longos excertos com que intercalamos o exercício de objetivação etnográfica não pretendem constituir "provas" em sentido positivista; são, antes, a tentativa de plasmar sobre o texto uma experiência que resiste à transcrição integral. Por outras palavras, tentar que a "prosa do mundo" se volva prosa literalmente. As variações sobre temas bakhtinianos, como podem ser vistas as sucessivas secções deste texto, pretendem revelar a sua proficuidade para a etnografia - e não apenas proporcionar um mostruário de noções ou trazer os nossos enunciados para a ribalta. Por isso, sondaremos as rugosidades do nosso material empírico com recurso a uma aparelhagem bakhtiniana, espécie de corante que releva incidências que são impercetíveis a um olhar contemplativo ou impávido. Neste texto, interessamo-nos sobretudo por salientar precisamente a interceção, sobre o terreno de pesquisa, ocorrida entre as propostas de Mikhail Bakhtin, postas em movimento como "perguntas" ou "interesses de pesquisa", e a massa de acontecimentos que preenche 
a banalidade da vida de todos os dias da fábrica e que puderam, em virtude do uso de utensílios bakhtinianos, aparecer nitidamente ao olhar etnográfico. Oportunamente, iremos remeter para sucintas ilustrações dos principais conceitos de Mikhail Bakhtin, sem ter, todavia, a veleidade de percorrer exaustivamente o seu vocabulário (para um glossário consistente, vd. Morson e Emerson 1990: 15-62).

Numa primeira secção do texto, iremos ver, portanto, como os trabalhos de Mikhail Bakhtin nos sensibilizaram para com a viscosidade da vida ordinária, tida usualmente por vulgar e insignificante. Neste ponto, iremos mostrar a importância que tem, para uma etnografia das práticas materiais e simbólicas dos operários, a recuperação da noção de "eventicidade", tão cara a Mikhail Bakhtin. ${ }^{3}$ Existem propriedades sensoriais e situacionais que só são expostas em estado vivo (ou conservadas apenas pelo decurso da ação) e que, por serem tão fugazes e tão comuns, são imperfeitamente registadas e repostas pelas recoleções verbais dos sujeitos, sobretudo quando surgem numa narrativa post festum. Numa segunda secção, vamos explorar a ampla reflexão de Mikhail Bakhtin a respeito da ideia de "contexto de enunciação". ${ }^{4}$ Neste caso em particular, iremos pugnar pela exploração da virtualidade epistemológica do conceito de "cronotopo" para a pesquisa etnográfica do mundo do trabalho. A terminar, tentaremos mostrar a importância da interpretação de Mikhail Bakhtin a respeito dos "pequenos mundos" (teórico, estético, ético) com que ele caracteriza a complexidade e a polinomia da existência humana. Essa inspeção do lugar próprio da "teoria" como criação ligada a uma esfera de atividade peculiar que, todavia, se concretiza em práticas pela aplicação a um contexto único e concreto, contém igualmente uma proposta de revisão do papel do etnógrafo: visto não só como "pensador", mas como uma variedade especial de "ator" que pode incorporar e aplicar a "teoria" em atos, ao mesmo tempo que consegue sustentar a vigilância epistemológica de si mesmo - o que lhe permite prevenir a "postura escolástica" pela qual o investigador se coloca acima do mundo que observa, sem deslizar para o impressionismo ingénuo ( $v d$. Bourdieu 2001). Desta maneira, sugere-se a virtualidade de praticar a etnografia como

3 Para Mikhail Bakhtin, a noção de "eventicidade" pretende restituir as propriedades específicas do engendramento da existência em evento, e não apenas a sua inclusão pelo evento: deste modo, remete-se para a natureza intrínseca e inescapável de atos enquanto ocorrem em evento; motivo que justifica a inventividade ligada a expressões como "ser-evento", "ser-como-evento" ou "evento-em-devir-do-ser". 4 Uma verbalização nunca seria compreendida ou explicada sem o seu "contexto de enunciação", constituído implicitamente pelo "horizonte comum aos interlocutores [composto] de elementos espaciotemporais, semânticos e avaliativos (axiológicos)" (Todorov 1984: 42). Desta maneira, Mikhail Bakhtin contesta simultaneamente a leitura estruturalista, para a qual as enunciações individuais são irrelevantes e, por outro lado, a escola subjetivista, que elimina as imputações sociais da verbalização singular. Para uma visão mais completa sobre a relevância da "sociabilidade" implantada nos contextos de enunciação, $v d$. Todorov (1984: 42-43). 
modalidade autorreflexiva de "pensamento participativo". ${ }^{5}$ Neste sentido, o texto permanecerá em estado de "inacabamento" ( $v d$. nota 2$)$ : ensaiando uma pesquisa etnográfica no universo quotidiano do trabalho industrial, ele vai ainda sujeitar o próprio impulso de etnografar às solicitações do pensamento de Mikhail Bakhtin. Antes de avançar para esta sequência de temas, comecemos, todavia, por proceder a uma paulatina aproximação ao terreno de pesquisa, caracterizando as circunstâncias sociais e históricas que circundam a comunidade sob investigação e apresentando sucintamente os procedimentos metodológicos usados nesta pesquisa etnográfica.

\section{TRANSCREVER A PROSA DO MUNDO: APROXIMAÇÕES AO TERRENO DE PESQUISA}

Rebordosa corresponde, em termos administrativos, a uma freguesia do concelho de Paredes, com uma população de 9106 habitantes (em 2001). Este concelho, com uma forte implantação das atividades industriais em termos latos, mostra uma particular especialização produtiva em torno do setor do mobiliário. Em 2001, a indústria do mobiliário representava 45,4\% dos trabalhadores do setor secundário do concelho de Paredes (e 27,3\% da população ativa). Segundo o relatório de uma associação empresarial nacional, o complexo industrial associado a este setor estava, por sua vez, pautado pela relevância que tinham as empresas de micro e pequena dimensão (cada unidade de produção empregava, em média, sete trabalhadores), caracterizadas por uma administração de cariz familiar e pouco formalizada, por um equipamento tecnológico incipiente ou pouco inovador, e pelas baixas remunerações e qualificações do pessoal empregado (AEP/Gabinete de Estudos 2005). ${ }^{6}$ A partir destas indicações sumárias, podemos situar o lugar específico ocupado pela "Empresa K" no interior da economia local de Rebordosa: veja-se

5 Nos termos originais de Mikhail Bakhtin, a ideia de "pensamento participativo" remete para o ponto de vista das pessoas empenhadas no contacto com coisas, pessoas e outros seres, partilhando-os e simpatizando com todos eles. Neste sentido, ela permite, assim, prevenir o ponto de vista separado do mundo, tirado "a partir de lado nenhum", como diria P.F. Strawson.

6 Uma outra caracterização do setor permite-nos complementar este retrato. O recenseamento industrial dedicado ao setor do mobiliário em Paredes contabilizava, em 2005, 1166 empresas, 258 delas em Rebordosa. Em termos gerais, tratava-se de microempresas (em média, cada qual conta com oito trabalhadores; 851 empresas têm dez ou menos trabalhadores), extremamente voláteis (436 foram criadas nos dez anos anteriores à realização do estudo), com uma estrutura produtiva tradicional (como sugere a reduzida presença de trabalhadores administrativos - 827 num total contabilizado de 8439 trabalhadores a tempo inteiro -, ou a subcontratação generalizada dos serviços de gestão financeira - 973 empresas estão nessa situação), e dedicadas sobretudo à revenda e à subcontratação (912 empresas afirmam dedicar-se à revenda, 836 empresas não têm exposição própria, 742 fazem móveis por medida). Tudo isto são elementos que parecem confirmar o retrato de um tecido produtivo pulverizado e instável (CMP/Paredes Rota dos Móveis 2005; Pereira 2006: 48-80). 
os 35 trabalhadores que empregava (incluindo os "encarregados" ou outros empregados, por exemplo), a posse de serviços administrativos especializados e profissionalizados (um "escritório" com um gerente e uma "engenheira"), a instalação de maquinaria que revelava módicas preocupações com a inovação tecnológica e com a normalização dos processos produtivos ("certificação de qualidade", "fichas de produção"), ou a utilização de procedimentos de publicidade pouco usuais entre as empresas de Rebordosa. Dotada destas propriedades, a empresa aparecia, segundo os parâmetros localmente prevalecentes, como uma unidade "moderna".

Durante 14 semanas, tivemos oportunidade de cumprir um horário de trabalho completo - começando às 8 horas e terminando às 18 horas, por vezes mais tarde, quando se realizavam "horas extraordinárias" - como manobrador de máquinas. $\mathrm{Na}$ realidade, o nosso trabalho correspondeu, inicialmente, ao patamar mais modesto das hierarquias técnica e estatutária do coletivo operário: como "moço" cumpríamos as tarefas sob a estrita vigilância de outro operário, a pedido de um "maquinista" mais experiente, ou como simples "ajudante de marceneiro". Só mais tarde, praticamente um mês após a entrada ao serviço, é que começámos a assegurar por nós próprios o controlo de uma máquina, aparentemente a que implicava menores competências prévias ("orladora"). $\mathrm{O}$ acesso ao terreno foi mediado por um contacto pessoal, que nos apresentou ao responsável pela administração da empresa como "estudante" que pretendia realizar uma "tese para a universidade". Da nossa concertação prévia nasceu o "contrato" implícito que viria a presidir à nossa presença sobre o terreno: nessa ocasião, tornámos patentes as motivações e as intenções do nosso trabalho de pesquisa; renunciámos a uma prestação salarial pelo nosso trabalho operário, pois que não pretendíamos que surgisse sequer a impressão de cumprirmos uma tarefa ou uma encomenda para a empresa como contrapartida por esse pagamento; comprometemo-nos a apresentar, terminada a nossa pesquisa de terreno, uma exposição sobre as nossas conclusões, salvaguardando, porém, os elementos pessoais dos trabalhadores; garantimos perante a empresa a nossa mais completa autonomia para a redação das conclusões da pesquisa, que ficou, por conseguinte, emancipada das interferências e aprovações da gerência. Ao longo da nossa permanência no terreno jamais perderíamos a vinculação com a instituição legítima que é a universidade - por isso, apenas como exemplo, sempre que um colega pretendia comprar uma peça de equipamento tecnológico, por muito que confessássemos a nossa ignorância sobre o assunto, era-nos pedido conselho. Em todo o caso, a presença continuada no terreno e, por consequência, a crescente integração nas intrincadas redes de interdependências que se vão entretecendo entre os colegas de trabalho, tanto em resposta às imposições técnicas do processo de trabalho, como em resultado da rotinização das trocas de "ajudas", "favores" e "obrigações" entre colegas, permitiu que o estigma de "estudante", invocado em termos irónicos, pudesse ser 
complementado, senão subalternizado pela condição de copresença na fábrica ("colega", "moço que ajuda"). As notas de campo, que foram por nós coligidas todos os dias, eram depois tratadas pessoalmente como "diários de campo".

Tendo por preocupação restituir a integralidade da experiência operária, regressaríamos no ano seguinte, em 2008, para residir em Rebordosa durante 16 semanas. Nessa altura, aproveitámos para interrogar as práticas e os sentidos que se concretizavam fora dos muros da fábrica: frequentando espaços de sociabilidade como cafés ou ginásios, encontrando os operários nos seus "tempos livres" em casa ou nos quintais, ligando-nos com eles em táticas de restituição de si e em ocasiões de valorização pessoal e coletiva (por exemplo, acompanhando uma equipa amadora de futebol). Por acréscimo ao nosso trabalho de observação etnográfica, realizámos entrevistas aprofundadas a operários a solo, casais de operários e outros atores locais ou setoriais relevantes, procurando com isto saturar as indicações de terreno com testemunhos que correspondessem com enunciações verbais às nossas solicitações, via perguntas semidiretivas. Pelas razões acima invocadas, vamos, neste texto, insistir sobretudo sobre as notas de campo que trazem para o papel os indícios dispersos pela fábrica, uma cultura com uma relevante componente somática, logo "muda", e constituída por marcadores verbais que não correspondem exata e integralmente aos protocolos da linguagem codificada.

\section{EXPLORAR O "MUNDO DA RAZÃO PRÁTICA":}

\section{A NATUREZA DE "EVENTICIDADE" DA PAUSA DO "LANCHE"}

Para Mikhail Bakhtin, é preciso "levar-em-conta" a unicidade do ato, em que se comprimem e exprimem todas as vertentes da existência do seu protagonista, para escapar às variedades da metafísica. Desta maneira, por exemplo, em vez de seccionar uma vertente unilateral de um ato para o interpretar analiticamente, impõe-se restituir a "mescla" entre "componentes" (que só aparecem como tal mediante uma desagregação extemporânea) que se opera nesse mesmo ato pela sua realização num certo contexto. Nos termos de Mikhail Bakhtin, entre o mundo-como-evento, o ato supera toda a hipótese; para o participante do ato, colocado sobre o plano do evento em processo, o mundo é compreendido a partir do seu inextrincável envolvimento pelo contexto de existência imediato. "Tudo em mim - cada movimento, gesto, experiência vivida, pensamento, sentimento - tudo deve ser um ato ou ação; é apenas sob esta condição que eu realmente vivo, que eu não me separo das raízes ontológicas do ser real. Eu existo no mundo da realidade inescapável, e não no mundo da possibilidade contingente" (Bakhtin 1993: 63). Esta pertença inexaurível do participante a um contexto particular constitui "a base tácita do seu não-álibi no Ser", o que nos impele a perceber as suas ações em combinação com as compulsões, valorizações e imputações que são inerentes ao 
"lugar próprio" ocupado por ele. Neste sentido é que se pode constatar que tais ações sejam realizadas "responsavelmente" perante as exigências que traz a participação ativa num contexto concreto (1993: 33-34, 50). Os participantes são transportados, implicados e comovidos pela natureza do evento que os compreende, ou pelo objeto que encaram, tomando-os uns e outros, eventos e objetos, não como produtos cristalizados, mas como produções "inacabadas", como "algo-ainda-por-ser-alcançado". Assim, o mundo vê-se tratado menos como uma "entidade pronta" do que como o movimento que o participante, por via de uma "atitude valorativa", procura realizar ou prevenir, manobrar ou contornar em razão da implicação que o mundo tem para si nesse instante. Nessa medida, o evento nunca está irreversivelmente terminado nem completamente isolado, surge integrado nesse fluxo que segue para "algo-ainda-a-ser-alcançado", pois as coisas ou as pessoas não são apenas conhecidas como "algo totalmente dado", mas, acima de tudo, dependem das variadas "atitudes valorativas" - ou "intonações" - que os participantes revelam e assumem em relação a elas, sejam tais atitudes expressas como ações, sensações ou pensamentos. Desta maneira, tais acontecimentos, coisas e pessoas tornam-se "momentos constituintes do evento vivo em processo" (1993: 38).

Estas observações acarretam consequências para a investigação etnográfica, levando-a a privilegiar compreender os contextos de "unicidade" onde os atos são "inescapável, irremediável e irrevocavelmente" executados (Bakhtin 1993: 47). Mergulhados na vida de todos os dias, não estamos colocados perante escolhas especulativas, ocasionais ou ilimitadas, que possam ser evitadas ou substituídas por outras; nela, somos "compelidos a agir" porque participamos de um contexto a que pertencemos empaticamente, que orienta o "sentido" e a "facticidade" do ato e que supera toda e qualquer "hipótese" (1993: 30). Embora "a cognição teórica de um objeto que exista por si, independentemente da sua posição real no mundo único do ponto de vista de um eu", seja perfeitamente justificada aos olhos de Mikhail Bakhtin, este mundo teórico só pode emergir, "com a sua própria lei imanente", com reivindicações de "universalidade" e "idealidade", portanto, para "um contemplador situado do lado de fora da arquitetónica do mundo" (1993: 70). Neste estado absoluto e abstrato, a "teoria" pura apenas se torna plausível ou imprescindível para uma perspetiva “exotópica" (1993: 75). Por seu turno, o "mundo da razão prática”, "o mundo no qual um ato ou ação realmente se desenvolve, no qual ele é realmente completado, é um mundo unitário e único, experimentado concretamente: é um mundo que é visto, tocado e pensado, um mundo impregnado no seu todo pelos tons emocionais-volitivos da validade afirmada dos valores" (1993: 59). Ele impõe uma temporalidade e uma espacialidade aos seus participantes, que são, portanto, absorvidos como seres incarnados, numa "comunhão única com o ser-evento" e que, sem ter que negar a validade da verdade científica no interior da circunscrição do mundo teórico (ou, nos seus respetivos mundos, 
a validade de apreciações morais ou estéticas), nenhuma instância de teoreticismo consegue substituir e compreender integralmente (1993: 10-11, 8).

$\mathrm{Na}$ "Empresa K", como noutras fábricas parecidas, são salientes as clivagens entre participantes, repartidos por uma rede de conexões estabelecidas em torno da competição pelo controlo do tempo-espaço, tanto o próprio como o alheio; tais clivagens são consequência da posse de assimétricos patrimónios de recursos estatutários e técnicos no interior da "configuração de poder" fabril (vd. Elias 1997). Desde logo, surgem separações físicas que traduzem a vinculação a postos de comando ou subordinados. Numa versão vertical das "regiões" goffmanianas, a organização material dos "quadros de interação" da empresa - embora o próprio Goffman tenha recusado, nos seus últimos livros, subscrever as "leis de ferro do lavor de palco" (Goffman 1986: 128) - impõe por si mesma um limite que separa os "escritórios", situados num plano arquitetónico e hierárquico superior, onde ocorrem as atividades de prescrição e supervisão da gerência, e o plano do "serrim”, o rés-do-chão da fábrica, onde se concentram os operários e as atividades de produção. Por sua vez, entre os operários, as partições podem ser criadas em razão da especialização técnica por secções. Podem também encontrar-se outros princípios de repartição salientes, como a hierarquia do prestígio magistral - ser ou não ser "artista", isto é, virtuoso - ou a condição etária ou sexual dos trabalhadores, que por vezes coincidem com a sua especialização técnica e hierárquica (vd. Monteiro 2014a: 72-81). Nestas circunstâncias, o funcionamento pacífico do processo de trabalho obriga a uma interdependência entre as sucessivas secções do processo de trabalho. Os marceneiros, por exemplo, precisam que os materiais - as "peças" - com que montam os móveis estejam em perfeitas condições, o que, como sucede frequentemente, obriga a ter que introduzir uma série de pequenas correções (em especial, realizar "cortes" ou "acertos"). Este ajustamento das "peças" com que trabalham os marceneiros é apenas possível por recurso aos maquinistas, que têm, no caso de concordarem com o "pedido" dos marceneiros, que interromper o trabalho em curso, controlado por fichas de produção e pelo controlo hierárquico dos tempos de produção, para executarem essa tarefa suplementar, tratada como "favor". Em troca, portanto, é usual que os marceneiros evitem expor os "gatos", isto é, as mensurações erradas ou os cortes com uma inclinação impraticável para serem montados, que os maquinistas cometem ocasionalmente.

Logo no início do nosso trabalho de campo, pudemos ver como se tornava importante, sobretudo quando pesavam circunstâncias de extrema urgência e de pressão patronal, a existência de uma colaboração entre os operários das várias secções, uma entreajuda que permitia corrigir os problemas crónicos do sistema de trabalho, usualmente surgidos do esgotamento da capacidade de reação do coletivo de trabalho (por exemplo, pelo volume inusitado de trabalho a executar num curto prazo ou pelo cansaço acumulado ao fim de sucessivas jornadas de trabalho prolongadas). Essa entreajuda servia também para 
encontrar soluções para contornar as perentórias regulamentações técnicas e legais que pesavam oficialmente sobre o trabalho, em particular mitigando a reatividade e velocidade de execução. Podemos apresentar uma longa lista de casos exemplares, desde as fichas de produção que contemplavam tarefas impraticáveis nos tempos previstos, até aos móveis cujas peças não eram todas perfeitamente conciliáveis e que obrigavam a improvisações (como a colocação de "chaços" nos móveis, pequenos pedaços de madeira que reforçavam ângulos e colagens). De resto, esta colaboração permitia superar instantaneamente os problemas surgidos de maneira imprevista (avarias, acidentes, absentismo).

"Os marceneiros tentam convencer, persuadir ou ameaçar os maquinistas a pararem e interromperem o seu trabalho para 'despacharem uma peça' que têm entre mãos. 'Anda lá, vê-me lá isto!', 'É só fazer aqui um corte'. Os marceneiros dependem da indulgência e das boas graças dos maquinistas, mesmo que se aventurem alguns deles a usar esporadicamente as máquinas" [nota de campo, 19 de janeiro de 2007].

Vemos, todavia, que este mecanismo de regulação não tem a natureza de um "aparelho", constituindo antes uma rede de interações multipolar e elástica que pode ser freada, paralisada ou inclusive rompida se suficientemente excitada por circunstâncias extraordinárias da fábrica.

Em particular, os momentos de celebração, como as pausas do "lanche", podem tornar-se ocasiões de saturação das interações operárias. Se é verdade que os "lanches" são ocasiões de enriquecimento sociabilitário, neles também se projetam frustrações e angústias e se constituem rancores e ressentimentos, o que inverte parcialmente a convicção de que funcionam apenas como momentos de relaxamento das imposições hierárquicas e produtivas. Nesses eventos, as opiniões verbalizadas pelos operários podem ser versões miscigenadas de "regimes de justificação" (como escrevem Luc Boltanski e Laurent Thévenot), combinando os registos de acusação e censura morais com o cálculo intuitivo de vantagens remuneratórias. O instante da vocalização mostra-se, assim, capaz de convocar pautas de justificações, espetros de sensibilidade e padrões de comportamento que coexistem entre si, por vezes numa fricção, numa sucessão ou numa alternância que os registos etnográficos e os próprios relatos operários parecem, não raras vezes, incapazes de apreender e restituir perfeitamente. Na seguinte nota de campo, onde realizámos um extenso relato que pretendia sumariar as observações de toda uma semana de trabalho, tornam-se patentes as ambivalências, os desacordos e a variedade de reações registados entre os operários em pleno "lanche": a pluriapreciação da qualidade da "obra" consoante a vinculação a distintos setores fabris, embora nos termos de um idioma partilhado sobre o trabalho. 
"Oscilações na intensidade da pressão hierárquica e no estado das relações do grupo entre si (a maior ou menor consistência dos pensamentos, palavras e obras realizadas em comum) podem provocar a irrupção de tensões ocultas. Uma conversa aparentemente inócua pode resvalar para o limiar da confrontação física (lanche, 10h). Tobias referia a superioridade da marcenaria. 'Ali, a ver aquele gajo [refere-se a Jonas, maquinista] a cortar placas, aprende-se o quê? Agora, aqui é que se vê como montámos, vê-se o móvel a nascer, vê-se as placas fora de medida que recebemos'. Esta simples palavra desencadeou uma reação da parte de Samuel, maquinista: 'Isso é normal. Se isto fosse matemática não era preciso tanta gente a trabalhar'. 'Mas podia ser melhor, há coisas que não se admitem', responde Tobias. Insolentemente, Samuel responde-lhe: 'Olha, se achas que os maquinistas não prestam, pegas e vais ao João [gerente] dizer-lhe'. 'Mas o que é que tu queres dizer com isso? Tamos a conversar ou a desconversar?' Samuel e Tobias estão sentados um ao lado do outro. A tensão eleva-se; o pessoal interrompe o lanche para assistir. Samuel insiste: 'Tou a dizer: já que tu tás aí a dizer que os maquinistas são uma merda, que não prestam, que vás dizer ao João isso. Eu vim para aqui aprender. Nunca tinha trabalhado numa esquadrejadeira. E dei-te obra sem estar em condições? Dou-te obra mal?' O tom eleva-se, quase que se berra. Inicia-se uma espiral de acusações: Tobias recorda casos anteriores e Samuel desafia-o a dizer publicamente se ele 'dá' ou não 'obra em condições'. Só eles os dois discutem. Este desfecho era já expectável, depois de nos últimos dias serem insistentes as referências veladas a uma 'escovalhice' [leia-se: bajulação] de Tobias a João, que era o gerente da empresa (ambos estiveram uns dias juntos na montagem do stand da empresa numa feira de mobiliário; por isso Tobias não estava sempre na fábrica e era apelidado 'pelas costas' de 'encarregado do stand'), e por Tobias supostamente receber, com mais um outro marceneiro, um valor compensatório pelos feriados, o que não acontecia com os restantes marceneiros. Este suposto favorecimento indevido, tanto de Tobias em relação a João, como vice-versa, aparece como duplamente ofensivo, já que Tobias é dos trabalhadores que, em grupo, mais abertamente reclamam por não se 'pagarem os feriados'. A ser verdade, Tobias é mentiroso e traidor.

O conflito é contido pela intervenção conciliatória de Jonas: 'Nunca vai ser perfeito. Pode andar para a frente muito, que nunca vai ser matemática. Isto são homens e errar é humano. Cometemos sempre erros. Agora, numa coisa ele [Tobias] tem razão, há coisas que podiam ir melhor. Não se admite alguma obra ir como vai. Mas isto está uma merda, tá uma confusão'. As prescrições técnicas embatem no facto incontornável - que é, em si mesmo, uma reivindicação - da humanidade dos operários. Samuel concorda que a obra 'não vai sempre bem'. Porém, procura desviar a 'culpa' - sempre essa preocupação com a culpa de alguém ou com as intenções de alguém ('sem 
intenção' equivale a inimputabilidade; 'temos de ver que o homem não teve culpa', diz-se para ilibar um patrão de atrasos no pagamento) - para as indicações erradas que se recebem no chão da fábrica: 'Até as fichas não vêm bem. No outro dia vinha 720 e era 72 [milímetros]. Já viste se eu fazia como estava na ficha? Eu vi e pensei: não; tirei como devia ser'. Isaías reforça esta linha de raciocínio: 'Se isto fosse tudo certo, ele tinha tirado as frentes com 700 e tal e não como deve ser'. Depois de terminar o lanche, Samuel havia de me dizer que 'mandou a boca' a Tobias e que 'era pa ele se aperceber' da sua insinuação” [nota de campo, 28 de fevereiro de 2007].

A fábrica é um contexto de enunciação, portanto, em que se permite a comunicação, mas onde também se reproduzem barreiras e clivagens entre os participantes. Os "discursos menores da vida quotidiana" da fábrica, que resultam da enunciação produzida na interação, preenchem a espessura simbólica do lugar, sem por isso se poder dizer que são incoerentes ou inconsequentes. Por um lado, a fábrica funciona como lugar onde são levadas a cabo enunciações sobre os acontecimentos e experiências da vida fabril, sendo evidente a "pluriacentuação" social das enunciações e trocas linguísticas que nela ocorrem de acordo com a posição valorativa das pessoas (Bakhtine 1977: 44). Em termos extremos, pode mesmo suceder que "cada palavra, sabemo-lo, apresenta-se como uma arena em miniatura onde se entrecruzam e lutam os acentos sociais com orientação contraditória" (1977: 67). Por outro lado, ela encastra estas variadas enunciações nos limites de um "tema" comum (1977: 142-143), fornecendo-lhe o quadro estável a partir do qual se cristalizam as convicções, os estereótipos e os motivos da linguagem operária. "Na realidade, o locutor serve-se da língua para as suas necessidades enunciativas concretas (para o locutor, a construção da língua está orientada para a enunciação, para a palavra). Trata-se, para ele, de utilizar as formas normalizadas (admitamos por agora a sua legitimidade) num dado contexto concreto. Para ele, o centro de gravidade da língua não se situa na conformidade à norma da forma utilizada, mas sim na nova significação que aquela toma no contexto" (1977: 99). Um tal entendimento permite-nos ponderar a "qualidade contextual" das enunciações prático-simbólicas dos operários. Os interlocutores, os operários em copresença sobre o chão da fábrica, não estão isolados das suas radicações sociais e económicas. As formas e as implicações da "enunciação atualizada" são transformadas tanto pela "situação de enunciação", como pelo seu "auditório" (1977: 123). "A enunciação é o produto da interação de dois indivíduos socialmente organizados e, mesmo que não haja um interlocutor real, nós podemos substituí-lo por um representante médio do grupo social ao qual pertence o locutor. A palavra dirige-se a um interlocutor; ela é função da pessoa desse interlocutor: ela variará conforme se trate de um homem do mesmo grupo social ou não, conforme ele seja inferior ou superior na hierarquia social, 
conforme ele esteja ligado ou não ao locutor por ligações sociais mais ou menos estreitas (pai, irmão, marido, etc.)" (1977: 138). Por isso, podemos apreciar as enunciações transcritas na nossa nota de campo como mais do que uma simples "irritação" entre operários: elas são a concretização verbal de um estilo expressivo que se vincula com a situação social ocupada pelos interlocutores no interior da empresa (respetivamente, as secções de marcenaria ou maquinaria) e com as polarizações e estratégias nascidas da repartição de oportunidades no interior da situação fabril do momento.

\section{UM “CRONOTOPO”: AS "REUNIÕES” ENTRE OPERÁRIOS E CHEFIAS}

Vemos que, para Mikhail Bakhtin, os "discursos menores da vida quotidiana" são "modelados pelo confronto da palavra contra o meio extraverbal e contra a palavra de outrem" (Bakhtine 1977: 138). No dia l de março de 2007, perante a excitação que nascera numa conversa a propósito da necessidade de recomeçar a prestar horas extraordinárias, encontrámos uma confirmação suplementar desta constatação bakhtiniana. Para o nosso autor, o centro de gravidade da enunciação encontra a sua significação no contexto de interação entre indivíduos "socialmente organizados" (1977: 115). Vistas unicamente a partir de uma visão consensualista da comunicação humana, as "reuniões" seriam prioritariamente uma ocasião para trocar informação ou para alcançar, por meio de uma negociação feita de concessões mútuas e ajustamentos recíprocos, um acordo. Todavia, a "intonação" adotada pelos operários revela a "qualidade contextual" das enunciações (1977: 100) empregues para conferir forma ao modo como essa mudança era vivida por eles. Por isso, veremos que as incompatibilidades, contradições ou discordâncias discursivas não são meras insuficiências, lacunas ou erros dos operários. Elas são a translação enunciativa de um modo de organização social peculiar: as discordâncias, contradições e incompatibilidades mostram que se travam, simultaneamente, lutas de sentido numa multiplicidade de terrenos, desdobrando-se entre os colegas operários por causa da sua descoincidência parcial de interesses, entre os operários e as chefias diretas pela imposição ou resistência ao comando, ou entre o piso térreo da fábrica visto no seu conjunto (incluindo, portanto, os "encarregados") e "os escritórios" onde estão a gerência e o serviço técnico.

Estas "reuniões", se os valores expressivos das enunciações exprimem (ou traduzem) o valor social dos respetivos enunciadores, servem elas também para reconstituir pela palavra as estruturas de poder que existem entre os enunciadores. Pautadas que são pelas margens de liberdade relativas que caracterizam as transações verbais entre enunciadores, tão mais contrastantes quanto maiores forem os hiatos de poder entre eles, as enunciações transmutam as polarizações sociais em termos propriamente verbais, como acontece com as prioridades de interpelação que existem nas conversas fabris (onde são 
os "encarregados" a ter frequentemente a iniciativa no uso da palavra) ou com as expressões de subserviência, como o silêncio ou o "atrapalhamento" em que os operários se enredam usualmente quando confrontados com as "ordens", ou seja, literalmente com as "palavras de ordem" pronunciadas pelas chefias. "A componente verbal do comportamento é determinada em todos os momentos essenciais do seu conteúdo por fatores objetivo-sociais. O meio social deu ao homem as palavras e uniu-as a determinados significados e apreciações; o mesmo meio social não cessa de determinar e controlar as reações verbalizadas do homem ao longo de toda a sua vida" (Bakhtin 2004: 86). As trocas linguísticas do momento são "pluriacentuadas", caracterizadas que são pelos diferentes potenciais de poder dos interlocutores, logo pelos interesses conexos e pelas estratégias que podem imaginar e mobilizar para os realizar. Estas trocas não correspondem, portanto, a uma simetria perfeita entre falantes. Elas têm também a natureza de um "processo" prolongado no tempo, realmente marcado pelo inacabamento a respeito das conclusões, equilíbrios e reações dos interlocutores, que se condicionam mutuamente pelas suas interações. Por sua vez, os reportórios de retórica usados pelos interlocutores são sensíveis não só às posições ocupadas atualmente no sistema de poder contemporâneo da fábrica, como igualmente aos trajetos biográficos percorridos ao longo do tempo pelos vários participantes de uma conversa. Por último, insista-se que nesses curtos e intermitentes episódios de interação, apesar da variação e trânsito que constantemente caracterizam os intercâmbios verbais, permanece um "fundo comum de consenso" entre todos os interlocutores. No entanto, essa conetividade surge unicamente a partir de um "consenso entre indivíduos socialmente organizados no decurso de um processo de interação" (Bakhtine 1977: 41). Em suma, os contextos de enunciação constituem "espaços de troca e conflito" onde são empregados e reatualizados os coeficientes de poder dos participantes, participantes que, longe de serem meros suportes de uma "estrutura social" que os transcende, continuamente a recriam nas suas interações em situação. Esta imbricação, porém, só é possível porque todos os participantes partilham convicções comuns sobre as regras e as hierarquias que, implicitamente, regulam as trocas verbais da fábrica, permitindo que as divergências e os acordos se possam manifestar em termos compreensíveis e relevantes para todos os participantes. Para discordar, em suma, requer-se concordar tacitamente sobre os termos da discórdia.

O longo registo que, a 1 de março de 2007, realizámos de uma "conversa" revela a subtileza das táticas empregadas pelos interlocutores de acordo com os seus interesses específicos no interior da trama de relações recíprocas de força da fábrica:

"Logo após o almoço, Daniel aproxima-se do espaço entre as esquadrejadeiras e chama, por gestos ou pelo nome, todos os maquinistas. 'É assim, 
tivemos lá em cima a falar [refere-se à 'reunião' semanal em que os três encarregados se encontram com o gerente para traçar os objetivos semanais e avaliar o estado presente da empresa] e parece que há obra para se fazer, há aí uns contentores para carregar. Era para ver quem é que pode começar a vir à noite'. 'Todos os dias?', pergunta Samuel alarmado. 'Não. Como dantes, às terças e quintas, [que era] o que estava' 'É assim, jeito não me dava, não é, mas falando-se, vê-se. Não te quero estar a dizer que sim, depois acontece alguma coisa, ou temos médico ou isso e não se pode vir...', diz Eliseu, numa resposta em que pouco se compromete. 'E já sabes que eu às segundas, quartas e quintas tenho curso [de desenho técnico]', indica Samuel, invocando dispensas. 'Claro. Isso dos cursos, continua assim, não se mexe', tranquiliza-o Daniel. 'Se se falar, as pessoas arranjam-se para poderem vir. Podias falar [a João, o gerente] em dar mais alguma coisa. Um incentivo para motivar as pessoas. Dar mais alguma coisa pelas horas extras...' (Samuel). 'Estilo uma percentagem, não é? A partir de certas horas dar mais um tanto' (Eliseu). 'Não podemos ser só nós a colaborar. Ele também tem de colaborar. Não podem ser sempre os mesmos. Ele tem que começar a ver o nosso lado, não é só foder o pessoal. As férias, como é que ficou? (Jonas) [refere-se ao pedido de mudança dos períodos de férias, que o gerente não permitiu]. 'Eu falei-lhe e ele disse que ia ver, que ia falar com o Fulano [patrão]. Mas não vos vou estar a enganar, bem sabeis que o mais certo é ficar tudo na mesma. Ele vai mandar o pessoal foder-se. Só se lhe der jeito, ou se a mulher em casa lhe pedir [risos], é que ele muda' (Daniel, encarregado). 'Se ele não mudar, já disse: não venho trabalhar nem mais uma ponte [intervalo entre feriado e fim-de-semana]. Ele que peça à vontade' (Samuel). [A conversa continua a este respeito, em termos idênticos.] 'É sempre para o mesmo lado. Nunca olha p'rá vida das pessoas!' (Jonas) 'Eu antes, ainda quero ter uma conversa com ele. Não vou dizer nada enquanto ele não vier falar comigo para resolver umas coisas' (Eliseu). Eliseu não teve, apesar das promessas do gerente, nenhum aumento nos últimos três anos. Ele pretende o aumento, de contrário ameaça enviar 'uma carta' para o patrão a lembrar-lhe todas as injustiças que sofreu desde que ali trabalha. 'Isso tens que ver com ele, já te disse o recado que ele me deu', responde-lhe Daniel, lembrando que o gerente tinha recusado o aumento. 'Já. Mas eu quero falar com ele' (Eliseu). 'O senhor vem, não vem? Disse-me na outra vez que...', diz Daniel para Esdras. 'Eu venho', limita-se este a responder. Estas foram as suas únicas palavras durante toda a conversa; acabou de dizê-las e afasta-se um pouco para trás, emudecendo definitivamente. Esdras é um maquinista recém-chegado à empresa e que está ainda 'à experiência'. 'Fala com ele para veres essas coisas. Diz-lhe que o pessoal já falou todo e que quer mudar as férias. E aquilo da compensação, para dar motivação ao pessoal. Mas não enroles, diz-lhe as coisas diretas' (Samuel). 'Vós bem sabeis que eu digo tudo. 
Eu digo exatamente o que me disserem, que é para não haver confusões. Se ele gostar, gosta, se não, azar’, diz Daniel, enquanto já se afasta, passando entre as placas de madeira, para se dirigir agora para uma 'conversa' idêntica com os marceneiros. A reunião acabou. Perto da banca de Abdias forma-se agora outro círculo. Não ouço o que aí se diz. Entre os maquinistas, começa a conversar-se dois a dois ou em pequenos grupos. Faz-se aí um momento de ponderação" [nota de campo, l de março de 2007].

Vale a pena tentar conhecer com minúcia o processo de negociação e acomodação recíprocas entre operários e chefias que se revela nestas "conversas". As "reuniões" entre os operários da secção de produção e o respetivo encarregado servem, assim, como instâncias de sondagem e auscultação dos humores operários; são uma espécie de plebiscito conduzido pelo encarregado, que tateia assim as roturas latentes entre as "secções" ou os eventuais antagonismos nas opiniões pessoais dos operários; são uma audiência prévia aproveitada pelos operários para insinuar ameaças, agitar espetros de protesto, mostrar respeito, recordar promessas. Forma-se pela conversa uma plataforma provisória de negociação - a que o gerente permanece estranho, pelo menos enquanto não são ultrapassados certos limites de tempo ou violência nas conversas - que visa assegurar a continuidade e estabilidade do processo de produção imediato. Mediante esta espécie de intercâmbio de dons e contradons (por isso se fala em "dar" horas, em fazer um "favor" ao patrão ou ao encarregado), todos os participantes visam satisfazer propósitos particulares: para a gerência, trata-se de conseguir uma produção relativamente pacífica e constante; para o encarregado, obter a prova cabal de que "cumpre com as suas obrigações" e de que "é respeitado" entre os operários (em sentido inverso, que "defende" os operários eficazmente perante o gerente); para os trabalhadores, tentar melhorias na sua condição ou a revisão de decisões patronais. Não se anula, em momento algum, a profunda assimetria de poder; mas esgrimem-se ameaças, ambições e irritações - que se acumulam e fazem perigar a ordem fabril.

"Nunca chegaremos às raízes verdadeiras e essenciais de uma enunciação singular se as procurarmos apenas nos limites de um organismo individual singular, mesmo quando tal enunciação se prende com os aspetos pelos vistos mais pessoais e íntimos da vida de um homem. Toda motivação do comportamento de um indivíduo, toda tomada de consciência de si mesmo (porque a consciência é sempre verbal, sempre consiste em encontrar um determinado complexo verbal) é a colocação de si mesmo sob determinada norma social, é, por assim dizer, a socialização de si mesmo e dos seus atos" (Bakhtin 2004: 86-87). 
Para compreender a lógica destas trocas de palavras, que parecem tantas vezes inconsequentes ou simples expressões sentimentais, revela-se a vantagem de utilizar a sugestão de Mikhail Bakhtin: vincular as palavras ao polígono social que organiza as enunciações e que elas contribuem para reiterar.

A partir das notas de campo apresentadas abaixo, que antecedem a nota de dia 1 de março acima transcrita e permitem perceber as circunstâncias da "reunião" ali relatada, podemos ver as circunvoluções que tem um conflito entre os operários e a gerência, intermediado pelas chefias, que também jogam aqui os seus peculiares perigos e proveitos. Tornam-se imediatamente percetíveis as interdependências que unem todos os participantes; a variedade de táticas de esquiva e simulação, choque, persuasão ou ocultamento que são usadas por uns e outros; a complexidade de orientações imaginárias e imputações materiais que se interligam com as ações e as palavras. Torna-se, enfim, saliente que a aparente apatia política destes operários, caracterizados pela escassez de vínculos sindicais e com um sentido de voto que não se pode considerar orientado para o protesto operário, esconde um compacto sedimento de "transcrições ocultas" (Scott 1991).

"Ao almoço, Daniel parece agitado. Começa por dizer: 'A partir de segunda ou terça, vai começar uma guerra do caralho. Há aí uns contentores para carregar; eles [os trabalhadores] vão-se mandar ao ar. É mais trabalho. Muito mais trabalho. Vão ter que ficar até mais tarde'. Tem andado nervoso. 'Se ele [João, gerente] não mudar as férias, a puta tá armada'. E depois, de maneira desconcertante: 'Mas se for ele [João] a pedir, eles já não dizem nada'. A insatisfação dele advém disso, de poder ser visto como pusilânime pelo patrão, por 'não ter mão' nos trabalhadores. Esta disputa pelas datas do período de férias arrastava-se há alguns dias. Não surgiu, entre os trabalhadores, uma concertação manifesta nem proclamações explícitas sobre os objetivos e os termos da reivindicação a esse respeito, limitando-se as conversas aos intervalos da jornada de trabalho ou, após a hora de almoço, ao breve encontro no café antes de seguir para a fábrica. Foi-se instalando entre eles, porém, uma convicção sobre o que 'dá' ou não ‘jeito' a um 'homem' nesta matéria, uma conivência sobre as pretensões e os limites até onde se poderia ir. O ajustamento de vontades operárias ocorreu implicitamente, abrigando-se no registo das evidências característico do senso comum: 'assume-se' o que 'tem que ser'; 'basta ter olhos na cara para ver como isto é'; 'isto não cabe na cabeça de ninguém'; 'não é preciso ser muito fino para saber disto'.

Perguntei a Samuel qual achava ele que seria o desfecho da conversa com o 'Roncas', o apelido depreciativo atribuído ao patrão Fulano. 'Nenhum. A gente não vem trabalhar, aposto que ele [João, o gerente] nem vai falar disso. Vai ficar assim'. Parecia que já tinha sido assumida uma atitude 
comum - mas onde?, perguntava-me eu - de que não se viria trabalhar na próxima 'ponte', daí a poucos dias.

A 12 de fevereiro, transmite-se a Daniel a intenção de ver a data das férias alterada. Durante o lanche, Daniel aproxima-se. 'Então, toda a gente quer mudar as férias para a segunda quinzena [de agosto]?' 'Diz-lhe [ao João, gerente] que o pessoal lá de baixo [isto é, o plano do chão da fábrica] quer mudar. Se ele não aceitar, queremos uma reunião [com ele]' (Samuel). ‘Temos de ser todos a colaborar. Não é só nós a colaborar e ele não’ (Amós). 'Quando ele precisar de nós para trabalhar, numa ponte ou assim, nós depois tiramos férias. Depois ele fica fodido...' Nestas poses de frontalidade perante o encarregado concentram-se os protestos individuais - sem que por um só momento surgisse a virtualidade de recorrer a entidades percebidas como estranhas, como os 'tribunais de trabalho', a 'inspeção de trabalho' ou os sindicatos. No entanto, reside aqui também um fator de inércia e relapsia das estruturas sociais da empresa: exigindo ou supondo uma igualdade transversal a trabalhadores e patrões por ocasião da negociação em situação interacional ('homem a homem', 'frente a frente', 'conversar com ele', 'não vou tar a criar problemas, falo com ele e pronto'), permanece intocada, inquestionada até, a desigualdade objetiva preexistente. A colaboração é 'trabalhar em comum', subentendendo-se, desta maneira, que todos os participantes estão em idêntica situação - o que é amplamente desmentido pela realidade.

Logo no dia seguinte, a 13 de fevereiro de 2007, faz-se saber a Daniel a concertação coletiva relativamente a não trabalhar na ponte. Logo depois de começarmos a trabalhar, às $8 \mathrm{~h}$, Daniel manda o pessoal parar o que está a fazer e chama toda a gente. 'É assim, o João diz que vai falar com o Fulano [patrão] para ver se dá para mudar as férias. Já houve também outras pessoas a falarem e é para ver se é para mudar. Agora, há outra coisa. Há mais trabalho. E se calhar vai ser preciso voltar ao que era em dezembro, em que terças e quintas tava-se até mais tarde'. A promessa de uma possível benevolência patronal vem acompanhada pela sugestão de uma contrapartida: os termos implícitos deste acordo presumem que, em caso de cedência patronal a respeito da marcação das férias, se espera uma cedência dos operários na questão das horas suplementares. 'Às terças e quintas e sábados de manhã?', pergunta Jonas. 'É. Ele falou também para o pessoal vir na segunda até às 6 horas', diz Daniel. Segunda-feira é véspera de Carnaval, estando previsto no 'mapa de férias', anunciado anteriormente, como dia de 'ponte'. 'Ontem até se falou nisso [como acima se mostrou, conjeturara-se já, durante as pausas, a iminência de haver um pedido patronal nesse sentido], e há muita gente [o conjunto de pessoas refere-se 'sem pôr nomes'] que não vem. Eles disseram que não dá. A mim, pessoalmente, também não dá muito jeito. Ao menos uma vez na vida, o pessoal queria ter um fim-de-semana prolongado', 
esclarece Eliseu. De modo nenhum este trabalhador pretendeu falar como representante ou porta-voz; muito menos é ele reconhecido como tal pelo restante pessoal. 'Tá bem. Então terças e quintas até mais tarde?', confirma Daniel, antes de voltarmos ao trabalho.

Pouco depois, às $10 \mathrm{~h}$, durante o lanche, haveria de se falar do que acontecera. Diz Jonas: 'Ai, se eles não mudarem as férias, sou eu que nem uma ponte venho trabalhar. Ainda perco dinheiro, porque deixo de receber a ponte [como dia de férias] e fazem-me [na mesma] os descontos'. Tobias: 'Ao menos podiam pagar os feriados. É que fica-se sem ganhar'. Abdias: 'Na Empresa Y [outra empresa], dá 25 euros. Não é muito, mas é algum. E se tivermos dois feriados num mês, já viste? É mais uma graça do que outra coisa. Mas dá muito jeito'. Jonas retoma a palavra: 'É, aqui não dá gosto nenhum trabalhar. Só vimos [trabalhar] mesmo porque, pronto...' Amós conclui a frase: "Porque temos que comer. Precisamos dele [o salário pago]" [notas de campo, 12 e 13 de fevereiro de 2007].

As intervenções verbais que acontecem sobre este contexto de enunciação são tingidas pelas circunstâncias sociais e históricas da fábrica, ou melhor, surgem filtradas pelo prisma das relações de poder peculiares em vigor no seu seio. Quisemos precaver-nos de impor à partida o conceito de "cronotopo", com isso podendo circunscrever o plano de experiências a abranger pela resposta. ${ }^{7}$ No entanto, após termos trazido um volume de material empírico apreciável, podemos agora sugerir o tratamento da "reunião" como cronotopo. Tendo em consideração os registos minuciosos das transações verbais e somáticas que acima transpusemos, podemos ver as “reuniões" como um lugar de organização da experiência social em que as enunciações dos participantes se sintonizam numa melodia peculiar, uma harmonização (não: harmonia) segundo as censuras e incentivos impostos pela materialidade do trabalho, pelos motivos e reportórios de conversação, pelos tópicos e ideias-comuns que são inerentes a esse contexto particular. Nos cronotopos, "concentradas, condensadas, evidentes e visíveis, encontram-se as marcas de um tempo histórico, de um tempo biográfico ou de um tempo quotidiano, e ao mesmo tempo tudo isto está confundido, fundado nos únicos índices da época, e esta última é percebida

7 Para complementar as palavras que incluímos no texto a seu respeito, acrescentemos que o "cronotopo" se prende com as representações discursivas, sejam elas literárias ou triviais, a respeito do espaço e do tempo, aparecendo simultaneamente como conceito cognitivo e como marca narrativa da linguagem. No entanto, revela-se possível alargar o âmbito de aplicação do conceito de "tempo-espaço" para "outras áreas da cultura”, como sugere o próprio Mikhail Bakhtin; para ele, a principal vantagem do termo residia em mostrar "a inseparabilidade do tempo e do espaço", em que o tempo se "densifica, ganha carne" e, por sua vez, o espaço se torna "carregado e reativo aos movimentos do tempo" (Bakhtin 1981: 84). Na comunidade científica portuguesa, vamos limitar-nos a reportar a invocação do conceito de “cronotopo" realizada por José Machado Pais (2002). 
concretamente, como sujeito" (Bakhtine 2001: 387). Desta maneira, cada cronotopo surge como um "lugar de interseção das séries espaciais e temporais, de condensação dos traços da marcha do tempo no espaço" (2001: 388). Na fábrica, o tempo e o espaço colapsam um sobre o outro, o tempo plasma-se sobre o espaço e vice-versa; os corpos são intercetados por esta imbricação, presos a ela, pois "o tempo adquire um caráter sensualmente concreto; no cronotopo, os acontecimentos [...] ganham corpo, revestem-se de carne, enchem-se de sangue" (2001: 391). Ao mesmo tempo, o cronotopo é um "ponto de interseção" concreto e imediato das vias pessoais e coletivas que são os percursos de vida de indivíduos que pertencem a uma pluralidade de "classes, situações, religiões, nacionalidades e idades". "As séries dos destinos e da vida do homem sob o seu aspeto espaciotemporal podem aí conhecer combinações variadas, complicadas e concretizadas em função das distâncias sociais, aí superadas. Neste ponto, se entrelaçam e se cumprem os acontecimentos" (2001: 385). ${ }^{8}$ Nele, estão condensados e concretizados variados "índices do tempo", nomeadamente o "tempo histórico" e o "tempo biográfico", precisamente por o tempo constituir o "centro organizador dos principais acontecimentos" e o "principal gerador do sujeito". No tempo mudam-se as realidades aparentemente mais consistentes. No "tempo quotidiano", por exemplo, tempo "viscoso" em que tudo acontece sem nada acontecer e tempo da "repetição" em que toda a novidade segue uma rotina, podem irromper "crises" nas quais o "tempo aparece como um instante" (2001: 389). Uma futura aplicação de um conceito como este promete alargar o espaço de inquirição que abrimos com o nosso trabalho; a ideia de "cronotopo" pode, assim, mostrar-se prenhe de heuristicidade fora do seu âmbito comum de aplicação, os estudos literários, tomando com isso uma viragem que poderíamos apelidar "sociológica", designadamente usando-a para interpretar a própria radicação da experiência social operária num circuito restrito de lugares territorialmente separados mas socialmente interligados entre si pela produção em comum de uma cultura significativamente coesa e genericamente partilhada pelo conjunto dos operários locais ( $v d$. Charlesworth 2000).

\section{NOTA FINAL: A ETNOGRAFIA COMO "PENSAMENTO PARTICIPATIVO"}

Os primeiros 20 anos do século XX viram suceder-se repetidas tentativas, entre as quais encontrámos também as obras iniciais de Mikhail Bakhtin, para interrogar e superar as convenções académicas em vigor. Naquela que será comummente reconhecida como a primeira etapa histórica e intelectual do

8 Esta caracterização do "cronotopo" refere-se originalmente ao "cronotopo do caminho". No caso por nós tratado, nem sempre se coloca a característica de "acidentalidade" dos encontros que era originalmente reportada por Mikhail Bakhtin para esta modalidade cronotópica (Bakhtine 2001: 285). 
percurso de Mikhail Bakhtin, encontramo-lo no centro de um círculo de discussão sobre temas literários e filosóficos ( $v d$. Clark e Holquist 1984: 35-62), primeiro em Nevel, depois em Vitebsk, ocupado com a empresa de "escapar ao neokantismo rumo a uma conceção mais sua" (1984: 54). A originalidade de Mikhail Bakhtin consistiu em recusar a lógica substancialista em que se encerrava a luta de posições entre conceções que se pensavam de maneira mutuamente exclusiva entre si (por exemplo, "idealismo" versus "materialismo"). Pela mesma altura, outros autores ocupavam-se com a releitura da herança filosófica (vd. Friedman 2000). Entre eles, Max Weber pensava em "esferas de atividade" ou "ordens de vida" caracterizadas por uma "lei ínsita" característica (1996: 41 1), tentando superar o hiato metodológico entre "explicação" e "compreensão" nas ciências sociais (vd. Ringer 1997). Da mesma maneira, Ernst Cassirer invoca a ideia de "formas simbólicas" para, em termos metodológicos, restituir sentido à pluralidade de modalidades de organização da perceção de que procedem as distintas representações da realidade, sejam elas os mitos, a ciência ou a arte. Deste modo, ao prestar atenção à "atividade espiritual" mais do que aos seus produtos acabados, Ernst Cassirer consegue respeitar a particularidade das "configurações" que reconstroem o mundo nos termos da lógica mitológica, científica ou artística (Cassirer 1972: 49). Reconhecendo uma pluralidade de "pequenos mundos", entre eles a teoria, a estética e a moral, Mikhail Bakhtin tentava vincar expressamente o caráter específico que tem o princípio de valorização que vigora internamente em cada um desses universos, sem os colocar sob uma norma transcendente e universal. Essas normas de ação específicas, impondo um modo de funcionamento peculiar sobre os participantes desses universos, eram apenas trasladadas de maneira enviesada pelos critérios e regras usadas noutros universos, os quais, por sua vez, retraduziam a experiência do mundo nos termos de uma outra lógica. Mikhail Bakhtin procurou mostrar que, tendo embora os indivíduos oportunidade de verter nos eventos únicos da existência princípios retirados de várias esferas de valorização em simultâneo, quando esses indivíduos procuram apreciar toda a existência por referência a um universo de significado e ação em particular, numa tentativa de interpretar esses eventos por analogia com apenas um universo de sentido, ou então extrapolando as regras deste para o conjunto da existência, incorrem num trespasse que transfere esquemas de pensamento e ação apropriados a esse "pequeno mundo" para outros, omitindo as suas lógicas específicas de inteligibilidade.

Para o caso particular dos usos da "teoria”, Mikhail Bakhtin tinha o propósito de tornar visível e prevenir a possibilidade latente de uma hipostasiação da "consciência universal", a postura hiperbólica que passa por pretender não apenas atingir a racionalidade que caracteriza uma representação científica do mundo, como ainda por tomar a teoria como "fundamento" ou "princípio" para o "contexto unitário da vida real" das pessoas. Nestes casos, quando uma 
maneira de conceber teoricamente o mundo, aplicada ao mundo, se erige em regra de produção do próprio mundo, a visão intelectual sobre a realidade social tende a converter-se em modelo implícito da realidade social. Por seu turno, ao ignorar o hiato existente entre a "concretude histórica de um facto individual" e o "momento formal de um juízo" (Bakhtin 1993: 22), a tentação do teoreticismo presume que as pessoas têm a teoria da sua própria ação e que, em consequência da consciência transparente da vida, se conduzem e se orientam precisamente pelos princípios, silogismos e previsões que procederiam da aplicação dos enunciados da teoria abstrata. Por exemplo, a respeito da ética, Mikhail Bakhtin mostra que ela "não tem um conteúdo especificamente teórico", ela surge, antes, interligada com a integridade das pessoas que a põem em prática como "ação em processo" (1993: 23-24). Nada impede, todavia, a validade do "mundo teórico". "A cognição teórica de um objeto que exista por si, independentemente da sua posição real no mundo único do ponto de vista do lugar único de um participante, é perfeitamente justificada" (1993: 51). O que importa, isso sim, é impedir que se tomem os princípios de natureza teórica (ou estética ou moral), que podem ser usados para entender nesses termos a existência, como a causa primeira das orientações práticas que predominam na "vida-como-evento": uma transferência comum a todas as variantes de "teoreticismo", que pressupõe a perfeita identidade entre a "historicidade abstratamente conhecida" e a "temporalidade da historicidade real do ser".? Desta maneira, vê-se que, mais do que invalidar as pretensões da "teoria", se trata de explicitar os limites em que se movem as representações teóricas do mundo.

Para cumprir precisamente com o pensamento de Mikhail Bakhtin, é preciso ver nas abstrações teóricas, estéticas ou morais apenas parte e parcela dos eventos do mundo; inclusivamente, o "sujeito teórico" precisa de estar incorporado por um "sujeito real" para se tornar totalmente ativo (Bakhtin 1993: 7). As visões teóricas ou estéticas ou morais apenas são justificadas enquanto não forem além dos seus próprios limites, elas que tentam, tantas vezes, "fazer passar uma parte abstratamente isolada como o todo real" (1993: 18). Ocorre na "cognição teórica" um processo semelhante ao que sucede com a "contemplação estética" ou com a "prescrição normativa", pois em todas

9 Neste momento, vale a pena ler uma passagem escrita pelo próprio Mikhail Bakhtin: "Na medida em que o mundo autónomo abstratamente teórico (um mundo fundamentalmente e essencialmente alheio à historicidade única e viva) permaneça dentro dos seus limites, a sua autonomia é justificável e inviolável. Tais disciplinas filosóficas, como a lógica, a teoria da cognição, a psicologia da cognição, a biologia filosófica (todas elas procurando descobrir - teoricamente, isto é, por meio da cognição abstrata - a estrutura do mundo teoricamente conhecido e os princípios desse mundo) são igualmente justificáveis. Mas o mundo como objeto de cognição teórica procura fazer-se passar como o mundo inteiro, isto é, não apenas como um ser abstratamente unitário, mas também como um ser concretamente único na sua possível totalidade" (1993: 25). 
elas, em primeiro lugar, tende a ser elaborada uma "metafísica" que traduz, nos termos próprios do seu domínio específico, a rotura em relação aos atos iterativamente concretizados por indivíduos sensíveis e atuantes. Existe, em combinação com essa conviçcão, a inclinação para "conceber", "apreciar" e "julgar" o mundo unicamente a partir do ponto de vista exotópico que as caracteriza (respetivamente: teórico, estético e moral), quer dizer, ponto de vista "situado-do-lado-de-fora" perante os contextos de ação concretos. Se o esforço de rotura com o ato concreto constitui, por si, um procedimento preliminar necessário para a constituição e conservação de uma transcrição teórica do mundo, que se governa "com as suas leis autónomas" (1993: 8), já a essencialização do registo teórico (ou estético ou moral) conduz a "um estado particular de esterilidade”, a uma obsessão com problemas, hierarquias e antíteses que são puramente intelectuais e que não têm validade a não ser no mundo teórico em que se produzem, tais como as oposições irredutíveis entre objetivo e subjetivo, forma e conteúdo, sentido e facto, resultado e processo, particular e universal $(1993: 39,47)$. Por sua vez, o comprazimento característico de um certo impressionismo que procede pela compilação e colagem de sensações e intuições tidas por "autênticas" ou "espontâneas", usado em etnografia para justificar a sobranceria em relação ao registo rigoroso e articulado da "ciência normal", i.e. a discussão argumentada entre colegas ou a utilização de conceitos e instrumentos da disciplina, constitui uma solução ilusória que parece ignorar que os próprios sentidos do investigador e, logo, o seu estilo de seleção e inscrição das impressões sensoriais estão já marcados por um tom emocional-volitivo e pela pertença a "um lugar próprio no ser-evento" (1993: 31).

Em termos genéricos, Mikhail Bakhtin simplesmente constata que a "teoria", incarnada pelo cientista (aqui, etnógrafo), "toma corpo" literalmente, surgindo "realizada e suportada pelo homem todo: pensamento, sentimento e corpo" (Bakhtine 1970: 57). A aceitação da premência que tem este "princípio material e corporal", que, desde logo, "se opõe a qualquer corte com as raízes materiais e corporais do mundo, a todo o isolamento e confinamento em si mesmo, a todo o caráter ideal abstrato, a todas as pretensões a uma significação desligada e independente da terra e do corpo" (1970: 28), permite, em seguida, sugerir uma outra conceção de etnografia, uma que não só sinaliza os limites da imagem teórica do mundo, mas que tira também consequências sobre a natureza impreterivelmente situada do trabalho do etnógrafo. Dito laconicamente, a proposta de Mikhail Bakhtin torna-nos cientes das condições sociais e intelectuais que são necessárias para a execução de uma conceção teórica do mundo, tal como nos conduz de volta ao lugar onde a prática acontece com esse suplemento de consciência sobre os limites da versão teórica do mundo e sobre a necessidade que consiste em experimentar a "eventicidade" de maneira participativa. 
“[O] evento único do ser não é apenas algo que é pensado, mas algo que é, alguma coisa que está a ser real e inescapavelmente realizada através de mim e de outros (completado, inter alia, também na minha ação de conhecer); ele é realmente experimentado, afirmado, de uma maneira emocional-volitiva, e a cognição constitui apenas um momento desse experimentar-afirmar" (Bakhtin 1993: 30).

Uma tal opção significa sinalizar, interrogar e renovar as noções tradicionais, as rotinas inquestionadas, as pseudoexplicações involuntárias que se misturam ao trabalho etnográfico, no sentido de as submeter, elas também, às práticas concretas de pesquisa e inteleção.

Esta proposta equivale a entender a etnografia como processo de pensamento em estado prático submetido à autorreflexividade do etnógrafo. ${ }^{10}$ Nesta variante, o "pensamento participativo" significa, por um lado, uma aplicação da teoria aos contextos valorativos concretos por força de uma encarnação (Bakhtin 1993: 57) e, por outro, a aplicação sistemática de uma reflexividade sobre a unicidade ou singularidade do lugar único ocupado pelas pessoas e, em particular, pelo próprio etnógrafo nos contextos de ação. Ação que, segundo a conceção de Mikhail Bakhtin, pode abranger o pensamento, a contemplação ou o conhecimento (1993: 51). O regresso ao "evento em processo" significa passar do estudo dos "produtos" para o estudo dos "atos" que os constituem e reconstituem sobre o mundo da ação; uma incursão pelas variedades de "arquitetónica concreta do mundo real do ato realizado", cujos momentos centrais são, para Mikhail Bakhtin, "eu-para-mim”, o "outro-para-mim" e "eu-para-o-outro" (1993: 56). Esta visão de um pensamento participativo vem contrariar as conceções escolásticas do conhecimento teórico, sem transigir, todavia, com a renúncia relativamente às tarefas de investigação e interpretação da etnografia. Afinal, a pesquisa de terreno etnográfica mostra-se especialmente coincidente com a ideia bakhtiniana de um "ato realizado" num contexto concreto, que, em vez de ser visto apenas como "um facto contemplado de fora ou pensado teoricamente", pode ser responsavelmente "levado-em-conta", com "a sua validade teórica, a sua factualidade histórica e o seu tom emocional-volitivo a figurarem como momentos de uma só decisão ou resolução" (1993: 45).

10 Esta aparente imbricação de atos reportados a universos de ação distintos torna-se possível e explica-se, segundo Mikhail Bakhtin, pela ocorrência de uma convergência sobre o evento único que aproxima a razão teórica e a razão prática, como se verifica pela seguinte passagem: "Toda a razão teórica na sua totalidade é apenas um momento da razão prática, isto é, a razão da orientação moral única do sujeito, no interior do evento do ser único. Este ser não pode ser determinado nas categorias da consciência teórica não participante - ele pode ser determinado apenas nas categorias da comunhão real, isto é, de um ato realmente realizado, nas categorias da experiência efetiva-participativa da unicidade ou singularidade concreta do mundo" (1993: 31). 
Em suma, a etnografia insinua-se neste texto menos como um "texto" do que como uma "prática", consistindo em atos e pensamentos de um determinado ser incarnado, o etnógrafo, que participa de um contexto situado ao mesmo tempo que possui os instrumentos para interrogar essa absorção pela situação. O etnógrafo, enquanto observa os outros com que interatua, pode igualmente conduzir uma reflexão sobre si mesmo, vigiando e registando a sua presença também. A partir deste empenhamento participativo, o etnógrafo precavê-se de supor que a maneira de registar que aplica à realidade descrita constitui a regra de produção de tal realidade ou, por outras palavras, precavê-se de converter a sua visão teórica sobre a realidade social em modelo implícito da realidade social que observa. Por outro lado, mediante o uso de conceitos e instrumentos de objetivação etnográfica, ele pode impedir-se de tomar a visão espontânea dos ocupantes habituais de um lugar geográfico e social como a única e exclusiva versão de representação do mundo social. Pela encarnação e pela (auto)reflexão que nasce da aplicação da etnografia como "pensamento participativo" sobre os contextos observados, o etnógrafo pode superar a separação estanque entre pensamento e ação, ou envolvimento e observação, prescrita pelo pensamento escolástico. Para retomar uma frase com que abrimos este texto: a "prosa do mundo" pode volver-se prosa simplesmente, embora ambas preservem a sua vinculação a universos distintos que não têm por que disputar prioridades relativas entre si. A vinculação do etnógrafo a ambos esses universos por via do "pensamento participativo" permite-lhe superar a unilateralidade de uma pertença exclusiva, impedindo que a reflexão teórica se divorcie da experiência vivida, e vice-versa. ${ }^{11}$ A realização desta exigência aparentemente contraditória é apenas possível pelo estatuto bicípite do etnógrafo. O exercício da etnografia como "pensamento participativo" permite recuperar a vinculação interessada e comprometida característica da existência prosaica e vivida das pessoas, sem que isso signifique comprazimento intuitivo perante o mundo ou absorção atónita pelo contexto envolvente. Pelo contrário, a oportunidade de utilizar a etnografia não só para registar o mundo envolvente, mas ainda para concretizar a autorreflexividade permite registar precisamente as circunstâncias e as implicações que acompanham o interesse e o comprometimento trazidos pela participação do etnógrafo nesses contextos. Para estender

11 Para Augusto Ponzio, a supressão da inclinação teoreticista passa precisamente por "encontrar um ponto de vista externo e ao mesmo tempo partícipe" a partir do qual se torne realizável uma "descrição" da "concreta arquitetónica do mundo real do ato, verbal e não-verbal, enquanto evento uno e único" (2012: 2). Para este autor, a visão de Mikhail Bakhtin sugere que "a interpretação-compreensão da arquitetónica pressupõe que essa se realize a partir de uma posição outra, diferente e ao mesmo tempo não-indiferente, mas por sua vez participativa. Só o ponto de vista do outro, na medida em que é externo e, portanto, capaz de um excedente 'transgrediente', permite que a descrição do mundo do eu não seja uma outra representação interna a esse mundo e, assim, limitada e parcial, uma re-presentação do relance do eu, mas uma visão compreensiva e envolvente, capaz de 'refiguração'" (2012: 4). 
as anotações de Augusto Ponzio (2012: 2-3) sobre as relações entre "autor" e "herói”, sem a participação não é possível uma "vivência" do evento, mas sem a alteridade (neste caso, permitida pela objetivação etnográfica) não é possível a sua "compreensão" e "interpretação". Se o etnógrafo vive esses contextos como um "eu" entre outros, que se imiscui nos eventos em que se empenha, ele pode também pensar-se a si mesmo como um "outro-eu" e trazer essa mesma experiência reflexiva para a pesquisa etnográfica (2012:3).

\section{BIBLIOGRAFIA}

ADLAM, Carol, 2001, "Critical work on the Bakhtin Circle: a new bibliographic essay", em Ken Hirschkop e David Sheperd (orgs.), Bakhtin and Cultural Theory. Manchester, Manchester University Press, 241-266 (2. a edição revista e ampliada).

AEP/Gabinete de Estudos, 2005, Indústria do Mobiliário. Porto, Associação Empresarial de Portugal, Gabinete de Estudos.

BAKHTINE, Mikhaill, 1970, L'oeuvre de François Rabelais et la culture populaire au Moyen Age et sous la Renaissance. Paris, Editions Gallimard.

BAKHTINE, Mikhail (V.S. Volochinov), 1977, Le marxisme et la philosophie du langage. Paris, Les Editions du Minuit.

BAKHTIN, M.M., 1981, The Dialogic Imagination: Four Essays. Austin, University of Texas Press.

BAKHTIN, M. M., 1993, Towards a Philosophy of the Act. Austin, University of Texas Press. BAKHTINE, Mikhaïl, 2001, Esthéthique et théorie du roman. Paris, Editions Gallimard.

BAKHTIN, Mikhail, 2004, O Freudismo. São Paulo, Editora Perspectiva.

BOURDIEU, Pierre, 2001, Science de la science et réflexivité. Paris, Editions Raisons d'Agir.

BRANDIST, Craig, e Galin TIHANOV (orgs.), 2000, Materializing Bakhtin: The Bakhtin Circle and Social Theory. Basingstoke, MacMillan Press.

CANGUILHEM, Georges, 1990, Etudes d'histoire et de philosophie des sciences. Paris, Vrin.

CASSIRER, Ernst, 1972, La philosophie des formes symboliques, volume 2. Paris, Les Editions de Minuit.

CHARlesworTH, Simon, 2000, A Phenomenology of Working Class Experience. Cambridge, Cambridge University Press.

CLARK, Katerina, e Michael HOLQUIST, 1984, Mikhail Bakhtin. Cambridge, MA, The Belknapp Press/Harvard University Press.

CMP/Paredes Rota dos Móveis, 2005, Recenseamento Industrial: Sector do Mobiliário - Paredes.

Paredes, CMP/Paredes Rota dos Móveis, documento policopiado.

ELIAS, Norbert, 1997, A Sociedade dos Indivíduos. Lisboa, Dom Quixote.

FRIEDMAN, Michael, 2000, A Parting of the Ways: Carnap, Cassirer, and Heidegger. Peru, IL, Open Court/Carus Publishing Company. 
GARDINER, Michael, 2003, “Editor's introduction”, em Michael Gardiner (org.), Mikhail Bakhtin, volume 1, Sage Masters of Modern Social Thought. Londres, Sage, x-xxvi.

GINGRAS, Yves (org.), 2014, Controverses: Accords et désaccords en sciences humaines et sociales. Paris, CNRS Editions.

GODZICH, Wald, 1991, “Correcting Kant: Bakhtin and intercultural interactions”, Boundary 2: An International Journal of Literature and Culture, 18 (2): 5-17.

GOFFMAN, Erving, 1986, Frame Analysis: An Essay on the Organization of Experience. Boston, Northeastern University Press.

HIRSCHKOP, Ken, e David SHEPERD (orgs.), 2001, Bakhtin and Cultural Theory. Manchester, Manchester University Press (2. ${ }^{\text {a }}$ edição revista e ampliada).

MONTEIRO, Bruno, 2014a, Frágil como o Mundo: Etnografia do Quotidiano Operário. Porto, Edições Afrontamento.

MONTEIRO, Bruno, 2014b, "Posfácio: Bakhtin vai a Rebordosa", em M. M. Bakhtin, Para Uma Filosofia do Acto. Porto, Deriva Editores, 105-153.

MORSON, Gary Saul, e Caryl EMERSON, 1990, Mikhail Bakhtin: Creation of a Prosaics. Stanford, Stanford University Press.

PAIS, José Machado, 2002, Sociologia da Vida Quotidiana: Teorias, Métodos e Estudos de Caso. Lisboa, Imprensa de Ciências Sociais.

PEREIRA, Fernanda, 2006, A Articulação da RRVS com a RM. Paredes, Universidade Fernando Pessoa/Ader-Sousa, trabalho apresentado à Universidade Fernando Pessoa no âmbito da pós-graduação em Marketing Integrado de Comunicação e Promoção do Turismo.

PONZIO, Augusto, 2012, "Il cronotopo letterario: confluenza di linguistica, etica ed estetica", comunicação apresentada em "Incontro di Prospettive: Figure e Forme del Narrare”, Università di Bari "Aldo Moro", 24-27 de outubro, disponível em < http://www. augustoponzio.com/files/augusto-ponzio,-il-cronotopo-letterario.pdf $>$ (última consulta em outubro de 2016).

RINGER, Fritz, 1997, Max Weber's Methodology: The Unification of the Cultural and Social Sciences. Cambridge, MA, Harvard University Press.

SCOTT, James, 1991, Domination and the Arts of Resistance. Yale, Yale University Press.

TODOROV, Tzvetan, 1984, Mikhail Bakhtin: The Dialogical Principle, Manchester, Manchester

University Press.

WEBER, Max, 1996, Sociologie de la religion. Paris, Flammarion. 